\title{
PEMBELAJARAN ILMU PENGETAHUAN SOSIAL TERPADU PADA SATUAN PENDIDIKAN MI/SD DAN MTs/SMP
}

\author{
Wahidmurni
}

\author{
Staf Pengajar pada Program Pasca Sarjana UIN Malang
}

\begin{abstract}
The curriculum development from 1994 curricula to 2006 curricula has been called as KTSP or (kurikulum tingkat satuan pelajaran). As the consequence of the development, the structure of social science knowledge has been changed accordingly. In this sense, the teachers need to adopt teaching models in terms of planning, actuating and evaluating. In short, it is important for teachers, who teach social science, mastering to the concept, attitude and life-skill. As the impact, the students' grades gradually increase.
\end{abstract}

Keywords: Pembelajaran, IPS Terpadu

\section{A. Pendahuluan}

Di masa yang akan datang peserta didik akan menghadapi tantangan berat karena kehidupan masyarakat global selalu mengalami perubahan setiap saat. Oleh karena itu kurikulum pendidikan harus dirancang dan implementasikan untuk menjawab tantangan global ini. Untuk menjawab tantangan ini, dalam dunia pendidikan kedudukan dan peran guru adalah sangat menentukan. Sebab dalam organisasi pendidikan, proses produktif pembelajaran yang paling ditekankan, dengan demikian guru adalah orang yang ada di garis terdepan pada proses pendidikan di sekolah/madrasah. Dia merupakan perancang, pelaksana dan pengevaluasi proses pembelajaran. Jadi tidak berlebihan jika dikatakan guru adalah orang yang paling tahu proses nyata yang terjadi di sekolah/madrasah. Oleh karena itu, guru harus selalu tanggap terhadap perkembangan ilmu dan teknologi yang berjalan dengan sangat cepat. Untuk itu, dapat dikatakan bahwa guru merupakan kunci dari segala usaha untuk mengembangkan sekolah/madrasah. Dengan demikian, upaya peningkatan mutu sekolah bahkan mutu pendidikan pada umumnya tanpa meningkatkan mutu gurunya merupakan upaya yang siasia.

Dalam pasal 1 ayat (1) Undang-Undang Republik Indonesia Nomor 14 tahun 2005 tentang Guru dan Dosen dinyatakan bahwa "Guru adalah pendidik profesional dengan tugas utama mendidik, mengajar, membimbing, mengarahkan, melatih, menilai dan mengevaluasi peserta didik pada pendidikan anak usia dini jalur pendidikan formal, pendidikan dasar, dan pendidikan menengah". Terkait dengan tugas pembelajaran, menurut Undang-Undang Republik Indonesia Nomor 20 tahun 2003 
tentang Sistem Pendidikan Nasional Pasal 39 ayat (2) dinyatakan bahwa "pendidik merupakan tenaga profesional yang bertugas merencanakan dan melaksanakan proses pembelajaran, menilai hasil pembelajaran, melakukan pembimbingan dan pelatihan, serta melakukan penelitian dan pengabdian kepada masyarakat, terutama bagi pendidik pada perguruan tinggi". Dalam konteks demikian sebenarnya guru dituntut untuk berperan sebagai sutradara, aktor sekaligus penonton kritis atas apa yang dia kerjakan. Sebagai sutradara ia dituntut untuk membuat skenario pembelajaran (rencana pembelajaran) yang akan dilaksanakan bersama siswa; sebagai aktor ia bersama siswa harus menjalankan peran sebagaimana yang dituntut dalam skenario yang telah ia buat; dan sebagai penonton kritis ia dituntut untuk selalu mengamati proses pembelajaran yang terjadi sebagai bahan refleksi untuk menentukan keberhasilan atau ketidakberhasilan program pembelajaran yang telah direncanakan dan dilaksanakan.

Secara umum tugas guru mata pelajaran IPS adalah sama dengan tugas guru mata pelajaran lainnya. Namun demikian dengan melihat karakteristik mata pelajaran IPS berbeda dengan mata pelajaran lainnya, maka setidaknya ada beberapa hal yang menjadi pembedanya. Misalnya, pada kurikulum sekarang ini (KTSP) ditekankan bahwa substansi mata pelajaran IPS merupakan IPS terpadu, maka tuntutannya adalah bahwa guru IPS sekarang ini harus memahami dan menerapkan model-model pembelajaran terpadu sebagaimana tuntutan kurikulum. Karakteristik IPS lainnya adalah bahwa masalah-masalah sosial kemasyarakatan sebagai obyek kajian IPS selalu berkembang terus menerus, maka sebagai guru mata pelajaran IPS dituntut untuk selalu mengikuti perkembangan itu agar apa yang diajarkannya selalu up to date (masalah-masalah terkini).

\section{B. Pembelajaran Mata Pelajaran IPS di Sekolah/Madrasah Saat Ini}

Ilmu Pengetahuan Sosial (IPS) merupakan salah satu mata pelajaran yang diberikan mulai dari SD/MI/SDLB sampai SMP/MTs/SMPLB, bahkan sampai pada jenjang SMK. IPS mengkaji seperangkat peristiwa, fakta, konsep, dan generalisasi yang berkaitan dengan isu sosial. Pada jenjang SMP/MTs mata pelajaran IPS memuat materi Geografi, Sejarah, Sosiologi, dan Ekonomi. Melalui mata pelajaran IPS, peserta didik diarahkan untuk dapat menjadi warga negara Indonesia yang demokratis, dan bertanggung jawab, serta warga dunia yang cinta damai.

Menurut lampiran Peraturan Menteri Pendidikan Nasional Republik Indonesia Nomor 22 tahun 2006, tentang Standar Isi untuk Satuan Pendidikan Dasar dan Menengah, butir Struktur Kurikulum Pendidikan Umum pada struktur kurikulum SD/MI point $b$, dinyatakan bahwa "substansi mata pelajaran IPA dan IPS pada SD/MI merupakan 'IPA terpadu' dan 'IPS terpadu' (2006:7). Demikian halnya untuk substansi mata pelajaran IPA dan IPS pada SMP/MTs juga merupakan 'IPA terpadu' 
dan 'IPS terpadu' (2006:9). Bahkan untuk jenjang pendidikan menengah, khususnya pada SMK/MAK, substansi mata pelajaran IPS juga disajikan sebagai 'IPS terpadu' (2006:17).

Secara terperinci penyajian mata pelajaran IPS terpadu pada jenjang pendidikan dasar dan menengah disajikan dalam tabel berikut:

Tabel 1. Penyajian Mata Pelajaran IPS Terpadu Pada Jenjang Pendidikan Dasar dan Menengah

\begin{tabular}{|c|c|c|c|c|c|c|c|c|c|c|c|c|c|}
\hline \multirow{2}{*}{ No } & \multirow{2}{*}{$\begin{array}{c}\text { Tingkat } \\
\text { Pendidikan }\end{array}$} & \multicolumn{12}{|c|}{ Kelas dan Alokasi Waktu } \\
\hline & & I & II & III & IV & $\mathbf{V}$ & VI & VII & VIII & IX & $X$ & XI & XII \\
\hline 1. & $\mathrm{SD} / \mathrm{MI}$ & \multicolumn{3}{|c|}{ TEMATIK } & 3 & 3 & 3 & - & - & - & - & - & - \\
\hline 2. & SMP/MTs & - & - & - & - & - & - & 4 & 4 & 4 & - & - & - \\
\hline 3. & SMA/MA & - & - & - & - & - & - & - & - & - & - & - & - \\
\hline 4. & SMK/MAK & - & - & - & - & - & - & - & - & - & & $28 \mathrm{Jc}$ & \\
\hline
\end{tabular}

Keterangan: Untuk mata pelajaran IPS di SMK durasi waktu 128 jam merupakan jumlah jam minimal yang digunakan oleh setiap program keahlian.

Mata pelajaran IPS disusun secara sistematis, komprehensif, dan terpadu dalam proses pembelajaran menuju kedewasaan dan keberhasilan dalam kehidupan di masyarakat. Dengan pendekatan tersebut diharapkan peserta didik akan memperoleh pemahaman yang lebih luas dan mendalam pada bidang ilmu yang berkaitan. Disiplin ilmu sosial yang termasuk dalam mata pelajaran IPS adalah (1) ilmu Geografi (aspek yang dipelajari mencakup manusia, tempat, dan lingkunga), (2) ilmu Sejarah (aspek yang dipelajari mencakup waktu, keberlanjutan, dan perubahan), (3) ilmu Sosiologi (aspek yang dipelajari mencakup sistem sosial dan budaya), dan (4) ilmu Ekonomi (aspek yang dipelajari mencakup perilaku ekonomi dan kesejahteraan).

Dengan demikian ada perbedaan mendasar pada tujuan mempelajari disiplin ilmu sosial dengan mempelajari IPS. Tujuan mempelajari disiplin ilmu sosial secara tersendiri adalah untuk menjadi ilmuan disiplin ilmu sosial yang dipilih (misalnya Ekonom, Sosiolog, Sejarahwan, dan sebagainya); sedangkan mempelajari mata pelajaran IPS sebagaimana dikemukakan oleh Banks (dalam Asmi, 2002:243) bertujuan untuk "membantu siswa mengembangkan pengetahuan, sikap, nilai dan kecakapan untuk menghadapi isu dan maslah sosial secara reflektif".

Adapun tujuan mempelajari mata pelajaran IPS sebagaimana dinyatakan dalam kurikulum IPS 2006 pada satuan pendidikan SD/MI dan 
satuan pendidikan SMP/MTs adalah bertujuan agar peserta didik memiliki kemampuan sebagai berikut; (1) mengenal konsep-konsep yang berkaitan dengan kehidupan masyarakat dan lingkungannya, (2) memiliki kemampuan dasar untuk berpikir logis dan kritis, rasa ingin tahu, inkuiri, memecahkan masalah, dan keterampilan dalam kehidupan sosial, (3) memiliki komitmen dan kesadaran terhadap nilai-nilai sosial dan kemanusiaan, dan (4) memiliki kemampuan berkomunikasi, bekerjasama dan berkompetisi dalam masyarakat yang majemuk, di tingkat lokal, nasional, dan global. Sedangkan tujuan mempelajari mata pelajaran IPS.

Menurut Asmi (2002: 243) dalam kenyataannya, di sekolah Indonesia sekarang keadaan ideal ini tidak tercapai. Walaupun dalam kurikulum sering disebut proses pembelajaran inkuiri, sebagaimana juga terlihat dalam rencana kurikulum baru, namun hal ini tidak terjadi dan terlaksana dengan baik di kelas. Pembelajaran IPS sangat menekankan jumlah pengetahuan yang harus dimiliki atau akumulasi pengetahuan yang berbentuk fakta dan teori (accumulated knowledge), lebih menekankan pada hafalan (rote learning) dari pada berpikir, sehingga dengan demikian siswa tidak terlatih melihat dan menghadapi kenyataan hidup yang sebenarnya. Penekanan yang lebih mengutamakan "learning accumulated knowledge" akan melemahkan prinsip pembelajaran "learning to learn", suatu kecakapan yang diperlukan untuk hidup. Akibatnya mata pelajaran IPS menjadi pelajaran yang tidak menarik siswa. Keadaan ini terutama dipicu pula oleh materi kurikulum yang padat dengan informasi dan ujian yang menekankan pada hafalan (recalling of knowledge/rote learning), ditambah dengan kurangnya media belajar yang tersedia.

Meskipun kurikulum sudah mengalami perubahan, yakni dari kurikulum 1994 menjadi kurikulum berbasis kompetensi (KBK) 2004 dan kurikulum 2006 (Kurikulum Tingkat Satuan Pendidikan/KTSP) yang keduanya tetap dapat disebut sebagai kurikulum berbasis kompetensi, namun pelaksanaan pembelajaran IPS tidak mengalami perubahan. Hal yang tidak berubah atau seringkali tetap sama dilakukan antara lain seperti: cara mengajar guru, materi pelajaran setiap disiplin ilmu yang tergabung dalam mata pelajaran IPS (terdiri atas kompetensi dasar Sosiologi, Sejarah, Geografi dan Ekonomi) tetap disajikan secara tersendiri tanpa dikaitkan dengan disiplin ilmu yang lain; jadi pola pengajaran yang diterapkan masih terpisah seperti pola kurikulum 1994 khususnya pada satuan pendidikan di SMP/MTs. Hal demikian terjadi karena di samping latar belakang pendidikan guru memang sudah terspesialisasi dalam pendidikan disiplin ilmu tertentu seperti pendidikan Ekonomi, pendidikan Sejarah, pendidikan Geografi, dan pendidikan Sosiologi sehingga merasa sudah menjadi tanggungjawabnya mengajar disiplin ilmu tersebut, juga rendahnya keterpahaman guru tentang konsep dan praktek pengajaran terpadu berdasarkan tema sebagaimana tuntutan kurikulum 2006. 
Perbedaan penyajian IPS terpadu pada satuan pendidikan MI/SD dengan satuan pendidikan MTs/SMP adalah jika pada satuan pendidikan MI/SD sebagaimana tertera dalam tabel 1. yakni untuk satuan pendidikan MI/SD kelas 1, 2 dan 3 atau yang disebut dengan kelas rendah pembelajaran dilakukan secara tematik, artinya bahwa pembelajaran mata pelajaran IPS harus disajikan secara tematik dengan mata pelajaran lain, seperti Matematika, IPA, Bahasa Indonesia dan sebagainya. Biasanya satu tema mencakup dari dua atau lebih KD-KD yang ada pada mata pelajaran yang ada pada struktur kurikulum di MI/SD. Pembelajaran di kelas rendah ini menggunakan pendekatan pembelajaran guru kelas. Sedangkan untuk kelas 4, 5, dan 6 atau yang disebut dengan kelas tinggi pada satuan pendidikan MI/SD pendekatan guru mata pelajaran yang diterapkan, sehingga model pembelajaran mata pelajarannya sama dengan yang berlaku pada satuan pendidikan MTs/SMP. Dengan demikian pengembangan kurikulum mata pelajaran IPS juga sama.

Oleh karena pembelajaran IPS dalam kurikulum 2006 merupakan IPS Terpadu yang merupakan gabungan antara berbagai disiplin ilmu-ilmu sosial, yang terdiri atas beberapa bagian disiplin ilmu terseleksi seperti Geografi, Sosiologi, Ekonomi, dan Sejarah, maka dalam pelaksanaannya tidak lagi terpisah-pisah melainkan menjadi satu kesatuan. Hal ini memberikan implikasi terhadap guru yang mengajar di kelas. Seyogianya (idealnya) guru dalam pembelajaran IPS dilakukan oleh seorang guru mata pelajaran, yakni Guru Mata Pelajaran IPS. Hal demikian juga ditunjukan oleh temuan penelitian Wahidmurni (2006: 60) yang menunjukkan bahwa telah terjadi perubahan kurikulum pada jenjang pendidikan dasar dan menengah, dari kurikulum 1994 ke kurikulum 2004 dan bahkan telah diterbitkan kurikulum 2006 yang pada saat ini sedang disosialisasikan pada lembaga-lembaga pendidikan di seluruh Indonesia. Lebih khusus kurikulum untuk mata pelajaran IPS di SD/MI, SMP/MTs, dan di SMK/MAK, yang dahulu mata pelajaran yang tergabung dalam IPS disajikan secara mandiri dan sekarang disajikan secara terintegrasi. Implikasinya sebagai lembaga atau program studi yang menghasilkan calon guru, direkomendasikan kepada fakultas Tarbiyah khususnya program studi Pendidikan IPS untuk segera menyesuaikan kurikulumnya guna memenuhi kebutuhan calon guru IPS di masa yang akan datang.

Untuk mengatasi kondisi di atas, sesungguhnya dapat dipecahkan dengan model pembelajaran team teaching, yakni suatu model pembelajaran yang terdiri dari beberapa orang guru (guru-guru mata pelajaran Sejarah, guru mata pelajaran Ekonomi, guru mata pelajaran Geografi, dan guru mata pelajaran Sosiologi dalam kurikulum 1994) bergabung menjadi satu tim yakni tim guru mata pelajaran IPS. Selanjutnya tim inilah yang bekerja memetakan berbagai standar kompetensi dan kompetensi dasar dalam kurikulum mata pelajaran IPS dan meramunya menjadi berbagai sajian pembelajaran berdasarkan tema yang disepakati bersama. Adapun dalam 
pelaksanaan pembelajaran guru yang tergabung dalam tim harus masuk ke kelas-kelas pembelajaran secara bersama-sama. Dalam pelaksanaan pembelajaran pembagian tugas di antara anggota tim dapat dilakukan, misalnya ketika sesi pembelajaran saat itu adalah pencapaian kompetensi dasar dari disiplin ilmu Ekonomi, maka guru intinya adalah guru Ekonomi sedang anggota tim yang lain bertugas membantu menciptakan kondisi pembelajaran yang lebih kondusif. Model pembelajaran seperti ini dapat dilaksanakan dengan baik jika dalam setiap sesi pembelajaran benar-benar menerapkan strategi pembelajaran aktif, di samping itu dengan menerapkan model pembelajaran team teaching ini beban mengajar guru sebanyak 24 jam perminggu dapat diatasi.

\section{Model Pembelajaran Mata Pelajaran IPS yang Disarankan}

Terkait dengan tugas pengajaran mata pelajaran IPS, guru dituntut untuk dapat menyajikan pengajarannya dengan menggunakan pendekatan tematik, sebab sebagaimana dinyatakan dalam Permendiknas nomor 22 tahun 2006 tentang Standar Isi bahwa substansi mata pelajaran IPA dan IPS pada SD/MI merupakan "IPA Terpadu" dan "IPS Terpadu"; demikian pula substansi mata pelajaran IPA dan IPS pada SMP/MTs juga merupakan "IPA Terpadu" dan "IPS Terpadu". Keterpaduan ini menuntut penyajian materi yang saling terkait antara disiplin ilmu-disiplin ilmu yang tergabung dalam mata pelajaran IPS, yakni Sosiologi, Sejarah, Geografi dan Ekonomi. Setiap standar kompetensi (SK) dan kompetensi dasar (KD) yang ada dalam kurikulum seharusnya dipetakan SK dan KD manakah yang dapat dipadukan, dan SK dan KD mana yang tidak dapat dipadukan, sehingga harus disajikan secara mandiri. Keterpaduan SK dan KD ini dapat diwujudkan dalam suatu tema-tema tertentu. Perwujudan tema-tema inilah yang seringkali kita sebut sebagai konsep pembelajaran tematik.

Pembelajaran tematik adalah pembelajaran yang menggunakan tema dalam mengaitkan beberapa mata pelajaran (atau beberapa disiplin ilmu yang tergabung dalam satu mata pelajaran tertentu seperti mata pelajaran IPS dan IPA), sehingga dapat memberikan pengalaman bermakna kepada siswa. Tema adalah pokok pikiran atau gagasan pokok yang menjadi pokok pembicaraan (Poerwadarminta, 1983). Dengan tema diharapkan akan memberikan banyak keuntungan, di antaranya: (1) siswa mudah memusatkan perhatian pada suatu tema tertentu, (2) siswa mampu mempelajari pengetahuan dan mengembangkan berbagai kompetensi dasar antar mata pelajaran dalam tema yang sama; (3) pemahaman terhadap materi pelajaran lebih mendalam dan berkesan; (4) kompetensi dasar dapat dikembangkan lebih baik dengan mengkaitkan matapelajaran lain dengan pengalaman pribadi siswa; (5) Siswa mampu lebih merasakan manfaat dan makna belajar karena materi disajikan dalam konteks tema yang jelas; (6) Siswa mampu lebih bergairah belajar karena dapat berkomunikasi dalam situasi nyata, untuk mengembangkan suatu 
kemampuan dalam satu mata pelajaran sekaligus mempelajari mata pelajaran lain; (7) guru dapat menghemat waktu karena mata pelajaran yang disajikan secara tematik dapat dipersiapkaan sekaligus dan diberikan dalam dua atau tiga pertemuan, waktu selebihnya dapat digunakan untuk kegiatan remedial, pemantapan, atau pengayaan.

Dalam menentukan tema dapat dilakukan dengan dua cara yakni: (1) mempelajari standar kompetensi dan kompetensi dasar yang terdapat dalam masing-masing disiplin ilmu yang tergabung dalam IPS, dilanjutkan dengan menentukan tema yang sesuai; dan (2) menetapkan terlebih dahulu tema-tema pengikat keterpaduan, dilanjutkan dengan mengidentifikasi kompetensi dasar dari beberapa disiplin ilmu yang tergabung dalam IPS yang cocok dengan tema yang ada.

Dalam menetapkan tema perlu memperhatikan beberapa prinsip yaitu: (1) memperhatikan lingkungan yang terdekat dengan siswa menuju lingkungan yang terjauh, (2) dari yang termudah menuju yang tersulit, (3) dari yang sederhana menuju yang kompleks, (4) dari yang konkret menuju ke yang abstrak, (5) tema yang dipilih harus memungkinkan terjadinya proses berpikir pada diri siswa, (6) ruang lingkup tema disesuaikan dengan usia dan perkembangan siswa, termasuk minat, kebutuhan, dan kemampuannya.

\section{Tahap Perencanaan Pembelajaran}

Keberhasilan pelaksanaan pembelajaran terpadu bergantung pada kesesuaian rencana yang dibuat dengan kondisi dan potensi siswa (minat, bakat, kebutuhan, dan kemampuan). Untuk menyusun perencanaan pembelajaran terpadu perlu dilakukan langkah-langkah berikut ini: (1) pemetaan SK dan KD untuk menentukan topik/tema, dan pengembangan Silabus dan Rencana Pelaksanaan Pembelajaran (RPP).

Pada langkah pemetaan SK dan KD dilakukan oleh tim guru IPS secara bersama-sama. Seyogyanya seluruh anggota tim harus hadir dalam acara ini, sebab pada acara pemetaan SK dan KD harus ada kesepakatan seluruh anggota tim tentang tema-tema sentral yang menjadi acuan dalam pembuatan silabus dan RPP. Pada tahap ini biasanya terjadi perdebatan yang sengit antar guru untuk menyepakati tema/topik yang akan menjadi acuan bersama. Contoh hasil pemetaan SK dan KD mata pelajaran IPS pada satuan pendidikan MTs/SMP adalah sebagai berikut:

Tabel 2. Peta Kompetensi Dasar yang Berpotensi IPS Terpadu Kelas VII MTs/SMP

\begin{tabular}{|c|c|c|c|c|c|}
\hline No & Geografi & Sosiologi & Ekonomi & Sejarah & Tema \\
\hline 1. & $\begin{array}{l}\text { Semester } 2 \\
4.1 \\
\quad \text { Menggunaka } \\
\text { n peta, at las, } \\
\text { dan globe }\end{array}$ & $\begin{array}{ll}\text { Semester 1 } \\
2.1 & \\
& \text { Mendeskripsik } \\
& \text { an interaksi } \\
& \text { sebagai proses }\end{array}$ & $\begin{array}{l}\text { Semester 2 } \\
\text { 3.1 Mendeskripsikan } \\
\text { manusia sebagai } \\
\text { makhluk sosial } \\
\text { dan ekonomi }\end{array}$ & $\begin{array}{l}\text { Semester } 2 \\
\text { 5.1 Mendeskripsikan } \\
\text { perkembangan } \\
\text { masyarakat, }\end{array}$ & $\begin{array}{l}\text { Pengem } \\
\text { bangan } \\
\text { Wisata }\end{array}$ \\
\hline
\end{tabular}




\begin{tabular}{|c|c|c|c|c|c|}
\hline No & Geografi & Sosiologi & Ekonomi & Sejarah & Tema \\
\hline & $\begin{array}{l}\text { untuk } \\
\text { mendapatkan } \\
\text { informasi } \\
\text { keruangan }\end{array}$ & $\begin{array}{ll}2.3 & \text { sosial } \\
& \text { Mengidentifik } \\
& \text { asi bentuk- } \\
& \text { bentuk } \\
& \text { interaksi sosial } \\
2.4 & \begin{array}{l}\text { Menguraikan } \\
\text { proses } \\
\text { interaksi sosial }\end{array}\end{array}$ & $\begin{array}{l}\text { yang bermoral } \\
\text { dalam memenuhi } \\
\text { kebut uhan } \\
\text { 6.2 Mendeskripsikan } \\
\text { kegiat an pokok } \\
\text { ekonomi yang } \\
\text { meliputi kegiatan } \\
\text { konsumsi, } \\
\text { produksi, dan } \\
\text { distribusi } \\
\text { barang/jasa }\end{array}$ & $\begin{array}{l}\text { kebudayaan dan } \\
\text { pemerintahan } \\
\text { pada masa } \\
\text { Hindu-Budha, } \\
\text { serta } \\
\text { peninggalan- } \\
\text { peninggalannya } \\
\text { 5.2 } \text { Mendeskripsikan } \\
\text { perkembangan } \\
\text { masyarakat, } \\
\text { kebudayaan, } \\
\text { dan } \\
\text { pemerintahan } \\
\text { pada masa } \\
\text { Islam di } \\
\text { Indonesia, serta } \\
\text { peninggalan- } \\
\text { peninggalannya }\end{array}$ & \\
\hline 2. & $\begin{array}{l}\text { Semester 1 } \\
1.1 \\
\text { Mendeskrips } \\
\text { ikan } \\
\text { keragaman } \\
\text { bentuk muka } \\
\text { bumi, proses } \\
\text { pembent uka } \\
\text { n, dan } \\
\text { dampaknya } \\
\text { terhadap } \\
\text { kehidupan } \\
\text { 4.2 Membuat } \\
\text { sketsa dan } \\
\text { peta wilayah } \\
\text { yang } \\
\text { menggamba } \\
\text { rkan objek } \\
\text { geografi }\end{array}$ & $\begin{array}{ll}\text { Semester 1 } \\
2.2 & \\
& \begin{array}{l}\text { Mendeskripsik } \\
\text { an sosialisasi }\end{array} \\
& \text { sebagai proses } \\
& \text { pembentukan } \\
& \text { kepribadian } \\
& \\
2.3 & \\
& \begin{array}{l}\text { Mengidentifik } \\
\text { asi bentuk- } \\
\text { bentuk } \\
\text { interaksi sosial }\end{array}\end{array}$ & $\begin{array}{l}\text { Semester } 1 \\
\text { 3.2 } \text { Mengident ifikasi } \\
\text { tindakan ekonomi } \\
\text { berdasarkan } \\
\text { motif dan prinsip } \\
\text { ekonomi dalam } \\
\text { berbagai kegiatan } \\
\text { sehari-hari } \\
\text { Semester } 2 \\
\text { 6.1 Mendeskripsikan } \\
\text { pola kegiatan } \\
\text { ekonomi } \\
\text { penduduk, } \\
\text { penggunaan } \\
\text { lahan dan pola } \\
\text { permukiman } \\
\text { berdasarkan } \\
\text { kondisi fisik } \\
\text { permukaan bumi }\end{array}$ & $\begin{array}{l}\text { Semester } 1 \\
\text { 1.2 Mendeskripsikan } \\
\text { kehidupan } \\
\text { pada masa } \\
\text { pra-aksara di } \\
\text { Indonesia }\end{array}$ & $\begin{array}{l}\text { Pola } \\
\text { Kegiatan } \\
\text { Ekonomi } \\
\text { Pendudu } \\
\mathrm{k}\end{array}$ \\
\hline 3. & $\begin{array}{l}\text { Semester } 2 \\
4.3 \\
\\
\text { Mendeskrips } \\
\text { ikan kondisi } \\
\text { geografis } \\
\text { dan } \\
\text { penduduk }\end{array}$ & Semester & $\begin{array}{l}\text { Semester } 2 \\
\text { 6.3 Mendeskripsikan } \\
\text { peran badan usaha, } \\
\text { termasuk koperasi, } \\
\text { sebagai tempat } \\
\text { berlangsungnya } \\
\text { proses produksi } \\
\text { dalam kaitannya } \\
\text { dengan pelaku } \\
\text { ekonomi } \\
\text { 6.4 Mengungkapkan } \\
\text { gagasan kreatif } \\
\text { dalam tindakan } \\
\text { ekonomi unt uk } \\
\text { mencapai } \\
\text { kemandirian dan } \\
\text { kesejahteraan }\end{array}$ & Semester & $\begin{array}{l}\text { Produk } \\
\text { Unggula } \\
\text { n Daerah }\end{array}$ \\
\hline 4. & $\begin{array}{l}\text { Semester } 2 \\
4.4 \\
\\
\quad \text { Mendeskrips } \\
\text { ikan gejala- } \\
\quad \text { gejala yang } \\
\text { terjadi di } \\
\end{array}$ & $\begin{array}{ll}\text { Semester 1 } \\
2.2 & \\
& \text { Mendeskripsik } \\
& \text { an sosialisasi } \\
& \text { sebagai proses } \\
& \text { pembent ukan } \\
\end{array}$ & $\begin{array}{l}\text { Semester 1 } \\
\text { 3.1 Mendeskripsikan } \\
\text { manusia sebagai } \\
\text { makhluk sosial dan } \\
\text { ekonomi yang } \\
\text { bermoral dalam }\end{array}$ & $\begin{array}{l}\text { Semester } 2 \\
\text { 5.3 } \text { Mendeskripsikan } \\
\text { perkembangan } \\
\text { masyarakat, } \\
\text { kebudayaan dan } \\
\text { pemerintahan } \\
\end{array}$ & $\begin{array}{l}\text { Kelangk } \\
\text { aan } \\
\text { Sumber } \\
\text { Daya } \\
\text { Alam }\end{array}$ \\
\hline
\end{tabular}




\begin{tabular}{|c|c|c|c|c|c|}
\hline No & Geografi & Sosiologi & Ekonomi & Sejarah & Tema \\
\hline & atmosfer dan & kepribadian & memenuhi & pada masa & \\
& $\begin{array}{l}\text { kidrosfer, } \\
\text { serta } \\
\text { dampaknya } \\
\text { terhadap } \\
\text { kehidupan }\end{array}$ & & & & \\
& & & & & \\
\hline
\end{tabular}

Beberapa hal yang perlu mendapat perhatian dalam pemetaan KDKD yang ada dalam mata pelajaran IPS adalah: (1) upayakan pemetaan dilakukan pada setiap kurikulum mata pelajaran IPS pada kelas tertentu saja yang terdiri atas dua semester, jangan mengabungkan dengan tingkatan kelas yang berbeda, (2) sedapat mungkin setiap KD dari disiplin ilmu sosial dapat dimasukan ke dalam tema yang disepakati, jika tidak dapat dimasukkan juga tidak boleh dipaksakan, (3) satu KD dari disiplin ilmu sosial yang ada dapat dimasukkan pada dua atau lebih tema yang ada, (4) jika ada KD disiplin ilmu sosial tertentu tidak dapat dimasukkan ke dalam tema yang ada, maka KD tersebut disajikan secara terpisah, dan (4) dalam satu tema dapat terdiri atas dua atau lebih KD dari suatu disiplin ilmu sosial tertentu.

Pada langkah pengembangan silabus dan penyusunan RPP dengan acuan sebagai berikut, untuk penyusunan silabus dibuat secara bersamasama oleh anggota tim sedangkan untuk penyusunan RPP disusun oleh masing-masing guru pengampu mata pelajaran IPS sesuai dengan disiplin ilmu yang dimiliki. Rambu-rambu yang harus diperhatikan dalam penyusunan RPP ini adalah sebagai berikut: (1) Silabus tematik yang telah disepakati menjadi acuan utama, dan (2) format RPP hendaknya diseragamkan antar guru.

Format silabus dapat berbentuk sebagai berikut:

Tabe1 3. Format Silabus Pembelajaran IPS Terpadu

Satuan Pendidikan $\quad$ : MI/SD atau MTs/SMP

Mata Pelajaran : Ilmu Pengetahuan Sosial

Kelas

Tema

Alokasi Waktu

menit

\begin{tabular}{|c|l|l|l|l|l|l|l|}
\hline $\begin{array}{c}\text { Disiplin IImu } \\
\text { Sosial }\end{array}$ & SK & KD & INDIKATOR & $\begin{array}{c}\text { PENGALAMAN } \\
\text { BELAJAR }\end{array}$ & PENILAIAN & $\begin{array}{c}\text { SUMBER } \\
\text { / ALAT/ } \\
\text { BAHAN }\end{array}$ & $\begin{array}{c}\text { ALOKASI } \\
\text { WAKTU }\end{array}$ \\
\hline Geografi & & & & & & & \\
\hline Ekonomi & & & & & & & \\
\hline Sosiologi & & & & & & \\
\hline Sejarah & & & & & & & \\
\hline
\end{tabular}


Adapun RPP dibuat secara individual dengan tetap terikat pada tema yang telah disepakati bersama (hal ini sebagai konsekuensi bahwa guru masih mengajar sesuai dengan bidang keahlian dalam disiplin ilmu sosial yang berdiri sendiri). Penjabaran KD menjadi indikator hasil belajar setidaknya sama tingkatannya dengan indikator-indikator pada model pembelajaran sebelumnya, atau bahkan lebih tinggi tingkatannya. Hal demikian dilakukan sebagai persiapan mata pelajaran IPS akan dimasukan sebagai mata pelajaran yang diujikan secara nasional.

Bentuk atau format RPP merupakan penjabaran secara operasional dari format silabus tematik yang telah disepakati, sehingga format RPP dapat berbentuk seperti berikut ini,

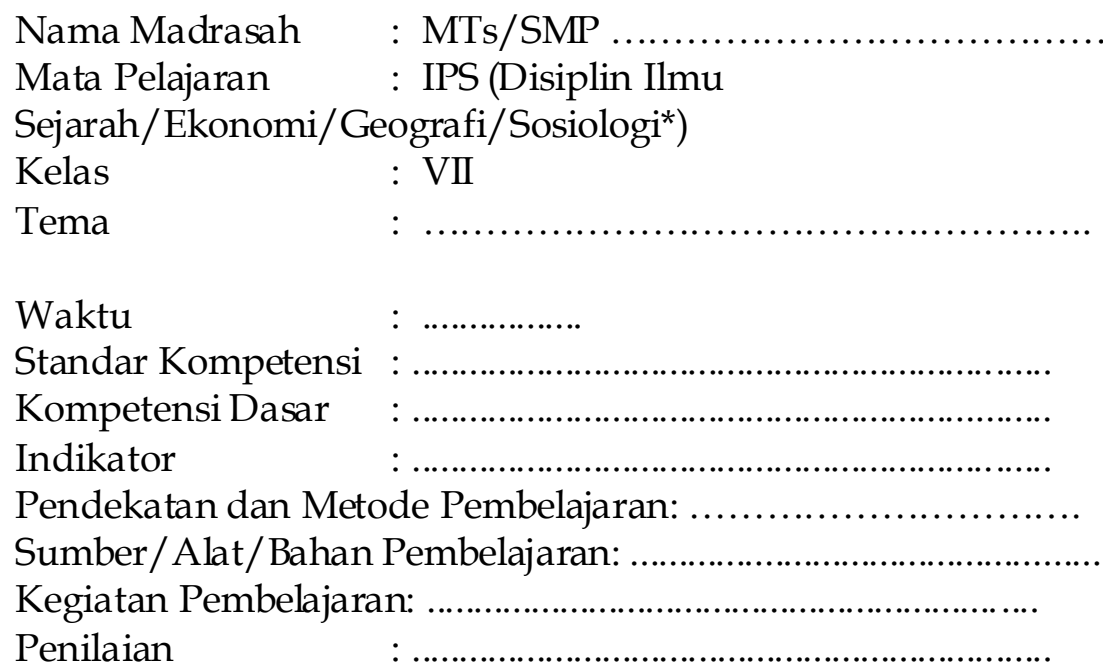

Komponen yang harus dijabarkan lebih rinci dalam RPP adalah komponen kegiatan pembelajaran dan penilaian. Komponen kegiatan pembelajaran harus menggambarkan secara rinci interaksi belajar antara siswa-guru dan sumber belajar. Sedangkan dalam komponen penilaian harus disertakan bentuk konkrit dari instrumen yang digunakan untuk mengukur ketercapaian kompetensi yang telah ditetapkan berikut rubrik penilaiannya.

\section{Tahap Pelaksanaan Pembelajaran}

Dalam tahap pelaksanaan pembelajaran dapat menerapkan model pembelajaran dengan menggunakan pola (1) model pembelajaran mandiri dan (2) model pembelajaran berkolaborasi. Model pembelajaran mandiri berarti setiap guru melaksanakan tugas pembelajaran secara individual dengan tetap beracuan pada tema (akan dapat berhasil dengan baik jika latar belakang pendidikan guru adalah dari program studi Pendidikan IPS, dan atau guru yang berlatar belakang pendidikan program studi pendidikan dalam disiplin ilmu sosial tertentu ditambah dengan bekal pelatihan atau program pendidikan IPS sebagai tambahan). Sedangkan 
model pembelajaran berkolaborasi berarti pelaksanaan pembelajaran diampu oleh beberapa orang guru, dimana satu orang guru bertindak sebagai guru inti dan guru lainnya membantu jalannya pembelajaran (ini dapat dilakukan oleh karena kondisi yang ada masih banyak guru yang berlatar belakang pendidikan program studi pendidikan ilmu sosial tertentu).

Pada saat ini, model yang disarankan adalah model pembelajaran berkolaborasi, sebab di samping masih banyaknya guru yang berlatar belakang pendidikan program studi pendidikan ilmu sosial tertentu juga karena dengan adanya kolaborasi akan memudahkan guru untuk memperbaiki program pembelajaran secara berkelanjutan; lebih-lebih dalam pelaksanaan pembelajaran diikuti dengan adanya penelitian tindakan kelas (PTK). Pembagian tugas di antara anggota tim setidaknya harus jelas dan tegas, sehingga suasana pembelajaran dapat diprotret/diamati secara lebih tajam sebagai bahan refleksi atas program pembelajaran yang telah dilaksanakan.

Dengan memperhatikan kerangka dasar dan struktur kurikulum sebagaimana tertuang dalam Permendiknas nomor 22 tahun 2006 tentang Standar Isi, maka dalam pelaksanaan program pembelajaran mata pelajaran IPS pada setiap satuan pendidikan (MI/SD, MTs/SMP dan SMK) menggunakan prinsip-prinsip sebagai berikut:

a. Pelaksanaan program pembelajaran mata pelajaran IPS harus didasarkan pada potensi, perkembangan dan kondisi peserta didik untuk menguasai kompetensi yang berguna bagi dirinya. Dalam hal ini peserta didik harus mendapatkan pelayanan pendidikan yang bermutu, serta memperoleh kesempatan untuk mengekspresikan dirinya secara bebas, dinamis dan menyenangkan selama mengikuti program pembelajaran.

b. Pembelajaran mata pelajaran IPS harus dilaksanakan dengan menegakkan kelima pilar belajar, yaitu: (a) belajar untuk beriman dan bertakwa kepada Tuhan Yang Maha Esa, (b) belajar untuk memahami dan menghayati, (c) belajar untuk mampu melaksanakan dan berbuat secara efektif, (d) belajar untuk hidup bersama dan berguna bagi orang lain, dan (e) belajar untuk membangun dan menemukan jati diri, melalui proses pembelajaran yang aktif, kreatif, efektif, dan menyenangkan.

c. Pelaksanaan pembelajaran mata pelajaran IPS harus memungkinkan peserta didik mendapat pelayanan yang bersifat perbaikan, pengayaan, dan/atau percepatan sesuai dengan potensi, tahap perkembangan, dan kondisi peserta didik dengan tetap memperhatikan keterpaduan pengembangan pribadi peserta didik yang berdimensi ke-Tuhanan, keindividuan, kesosialan, dan moral. 
d. Pembelajaran mata pelajaran IPS harus dilaksanakan dalam suasana hubungan peserta didik dan pendidik yang saling menerima dan menghargai, akrab, terbuka, dan hangat, dengan prinsip tut wuri handayani, ing madia mangun karsa, ing ngarsa sung tulada (di belakang memberikan daya dan kekuatan, di tengah membangun semangat dan prakarsa, di depan memberikan contoh dan teladan).

e. Pembelajaran mata pelajaran IPS harus dilaksanakan dengan menggunakan pendekatan multistrategi dan multimedia, sumber belajar dan teknologi yang memadai, dan memanfaatkan lingkungan sekitar sebagai sumber belajar, dengan prinsip alam takambang jadi guru (semua yang terjadi, tergelar dan berkembang di masyarakat dan lingkungan sekitar serta lingkungan alam semesta dijadikan sumber belajar, contoh dan teladan).

f. Pembelajaran mata pelajaran IPS harus dilaksanakan dengan mendayagunakan kondisi alam, sosial dan budaya serta kekayaan daerah untuk keberhasilan pendidikan dengan muatan seluruh bahan kajian secara optimal.

\section{Tahap Penilaian Pembelajaran}

Untuk memastikan bahwa pelaksanaan pembelajaran telah mencapai tujuan atau kompetensi yang ditetapkan dalam RPP diperlukan kegiatan penilaian pembelajaran. Penilaian pembelajaran dikatakan baik dan benar jika instrumen penilaian yang digunakan benar-benar mengukur apa yang seharusnya diukur.

Sistem penilaian yang dilakukan oleh sekolah/madrasah harus mengikuti pedoman atau prinsip penilaian yang telah ditetapkan oleh pemerintah melalui Permendiknas Nomor 20 Tahun 2007 tentang Standar Penilaian Pendidikan pada point B butir ke 8 yang menyatakan bahwa "prinsip penilaian beracuan kriteria, berarti penilaian didasarkan pada ukuran pencapaian kompetensi yang ditetapkan".

Oleh karena kurikulum KTSP berdasarkan kompetensi dan untuk mengukur dan menilai keberhasilan belajar menggunakan Penilaian Acuan Kriteria (PAK), hal ini sebagaimana dapat dilihat dari adanya ujian nasional yang penilaiannya juga menggunakan PAK; maka sistem penilaiannya juga menggunakan PAK yang operasionalisasinya di sekolah/madrasah pada saat ini dikenal dengan istilah Kriteria Ketuntasan Minimal (KKM). Besarnya skor KKM pada dasarnya diserahkan kepada sekolah/madrasah itu sendiri, karena sekolah/madrasah yang lebih tahu akan kondisi dirinya, misalnya bagaimana karakteristik sekolah/madrasah, bagaimana kondisi sumberdaya yang dimiliki, bagaimana karakteristik peserta didiknya dan sebagainya. Hal ini sebagaimana dinyatakan dalam Peraturan Menteri Pendidikan Nasional Republik Indonesia Nomor 20 Tahun 2007 tentang Standar Penilaian 
Pendidikan, sub bab Pengertian point 10 bahwa " kriteria ketuntasan minimal (KKM) adalah kriteria ketuntasan belajar (KKB) yang ditentukan oleh satuan pendidikan. KKM pada akhir jenjang satuan pendidikan untuk kelompok mata pelajaran selain ilmu pengetahuan dan teknologi merupakan nilai ambang batas kompetensi". Lebih lanjut tentang penentuan besaran KKM oleh satuan pendidikan harus memperhatikan karakteristik peserta didik, karakteristik mata pelajaran, dan kondisi satuan pendidikan melalui rapat dewan pendidik.

Untuk dapat menerapkan penilaian yang baik dibutuhkan penguasaan yang optimal tentang: (1) ranah penilaian hasil belajar, (2) penyusunan instrumen penilaian baik tes maupun non tes, (3) penentuan besaran kriteria ketuntasan minimal (KKM) hasil belajar siswa.

Dengan demikian pada tahap penilaian harus dilaksanakan secara matang oleh tim guru IPS. Format penilaian berikut besaran sekor KKM harus ditetapkan secara bersama oleh anggota tim guru mata pelajaran IPS pada awal tahun atau awal semester bersamaan dengan acara pemetaan SK dan KD dan penyusunan silabus. Hal demikian dilakukan untuk menghindari adanya perselisihan antar anggota tim ketika akan melaksanakan penilaian pembelajaran.

\section{Kesimpulan}

Perubahan kurikulum seringkali juga diikuti oleh perubahan paradigma dalam memandang dan melaksanakan kegiatan belajar dan mengajar, di samping banyak hal yang mengalami perubahan seperti: (1) penambahan mata pelajaran baru dan terhapusnya mata pelajaran yang lama, (2) diturunkannya lamanya jam belajar, (3) bergabungnya mata pelajaran menjadi satu mata pelajaran dan lain sebagainya. Bergabungnya beberapa mata pelajaran yang dahulunya disajikan secara mandiri/terpisah pada kurikulum 1994 terjadi pada mata pelajaran IPS dan mata pelajaran IPA pada kurikulum 2006 (KTSP) ini. Perubahan ini tentunya membawa konsekuensi bagi guru-guru mata pelajaran yang bergabung, misalnya jam mengajar yang berkurang, sementara tuntutan mengajar bertambah menjadi 24 jam per minggu (aturan sertifikasi). Perubahan yang terjadi harus diiikuti dan disiasati dengan baik oleh para guru, siasat tersebut adalah dengan cara melaksanakan pembelajaran model team teaching mengingat bahwa tuntutan kurikulum untuk mata pelajaran IPS juga mengarah pada model pembelajaran terpadu.

Untuk dapat melaksanakan model pembelajaran IPS terpadu dengan baik, menuntut kerja keras para guru yang tergabung dalam tim guru mata pelajaran IPS dalam penguasaan konsep dan ketrampilan dalam menerapkan model-model pembelajaran terpadu yang di dalamnya mencakup: (1) perencanaan pembelajaran IPS terpadu, 
model/pendekatan/strategi pembelajaran IPS terpadu, dan (3) modelmodel penilaian pembelajaran IPS terpadu.

\section{E. Daftar Pustaka}

Asmi. 2002. Ilmu Pengetahuan Sosial (IPS) Terpadu untuk Sekolah Menengah Umum (SMU). Ilmu Pengetahuan Sosial, Jurnal IPS dan Pengajarannya, Tahun 36, Nomor 2, Oktober: 240-251.

Kurikulum 2006 Mata Pelajaran Ilmu Pengetahuan Sosial untuk Sekolah Dasar (SD)/Madrasah Ibtidaiyah (MI)

Kurikulum 2006 Mata Pelajaran Ilmu Pengetahuan Sosial untuk Sekolah Menengah Pertama (SMP)/Madrasah Tsanawiyah (MTs)

Peraturan Menteri Pendidikan Nasional Republik Indonesia Nomor 22 Tahun 2006 tentang Standar Isi untuk Satuan Pendidikan Dasar dan Menengah.

Peraturan Menteri Pendidikan Nasional Republik Indonesia Nomor 20 Tahun 2007 tentang Standar Penilaian Pendidikan.

Undang-Undang Republik Indonesia Nomor 20 Tahun 2003 tentang Sistem Pendidikan Nasional (Sisdiknas) Beserta Penjelasannya. Bandung: Citra Umbara.

Wahidmurni. 2006. Asesmen Kebutuhan untuk Pengembangan Kurikulum Program Studi Pendidikan Ilmu Pengetahuan Sosial Fakultas Tarbiyah Universitas Islam Negeri (UIN) Malang. Malang: Penelitian Proyek Peningkatan Perguruan Tinggi Agama/Universitas Islam Negeri Malang. 